ORIGINAL ARTICLE

\title{
Association between Glucocorticosteroid Receptors (NR3C1) Gene Polymorphism and Bronchial Asthma in Children
}

\author{
Khalid Mohamed Salah ${ }^{1}$, Mona Mohamed Al Shafie ${ }^{1}$, Osama Abdelaziz Gaber ${ }^{2}$, Mahmoud \\ Tharwat Awad 1 * \\ ${ }^{1}$ Pediatric Department, Faculty of Medicine, Zagazig University, Zagazig, Egypt \\ ${ }^{2}$ Medical Biochemistry Department, Faculty of Medicine, Zagazig University, Zagazig, Egypt
}

* Corresponding author:

Mahmoud Tharwat Awad

Pediatric Department,

Faculty of Medicine, Zagazig

University, Zagazig, Egypt

mahmodtharwat@yahoo.com

Submit date:

Revise date:

Accept date

\section{ABSTRACT}

Background: There is a large variation in the magnitude of the response to asthma medications. Pharmacogenetics is responsible for a significant part of this variation. We aimed at studying the effect of the Glucocoricoid receptors NR3C1 BCLI single nucleotide polymorphism (SNP) on the susceptibility to bronchial asthma in children and to evaluate its effect on the response to inhaled corticosteroids (ICS). Method: Seventy five asthmatic children and a control group of 66 non asthmatic children were included in the study. The level of asthma symptom control and pulmonary function tests were measured initially and 3 months after treatment with inhaled corticosteroids. The genotypes were studied using PCR-RFLP method. Results: No statistically significant difference was found between asthmatic group and the control group as regard the studied genotype. Among asthmatic children, The CC genotype was statistically associated with controlled asthma symptoms 3 months after treatment and the GG genotype was associated with poor asthma symptom control. Also, FEV1\% after 3 months of treatment was statistically lower in children with the GG genotype as compared to children with the CG and CC genotypes. Conclusion: glucocorticoid receptor NR3C1 SNP was not associated with asthma susceptibility in the studied group. However, the presence of the GG genotype was associated with decreased response to ICSs among asthmatic children as regards asthma symptom control and FEV1\% response.

Key words: Asthma, Pharmacogenetics, Inhaled corticosteroids

\section{INTRODUCTION}

B ronchial asthma is an important global health problem which affects all age groups and its prevalence is increasing in many countries especially among children [1]. It is estimated to affect around 300 million people worldwide and is believed to be the most common chronic disease in children [2].

Inhaled corticosteroids (ICS) are the favored first-line treatment for persistent asthma. By binding to glucocorticoid receptors, they suppress the activation of inflammatory genes and modulate activity of genes involved in airway epithelial barrier and airway remodeling [3]. There is a large variation in the magnitude of the response to asthma medication, and around $5-15 \%$ of asthmatic children fail to respond to ICS and they are often treated with high doses of ICS, which then has the potential to cause significant side-effects [3]. While part of this heterogeneity of response is due to adherence and environmental effects, genetic variations also influence the response to treatment and genetic markers may help to guide treatment [5].

The NR3C1 gene which encodes the glucocorticosteroid receptor (GCR) is localized on chromosome 5q31-q32 and consists of nine exons. Single nucleotide polymorphisms; SNPs; within this gene may have a regulatory effect on expression and lead to changes in the RNA splicing process, thus affects the Gluccorticoid sensitivity [6]. 
We conducted a pharmacogenetic study nucleotide polymorphism of the NR3C 1 gene on the response to inhaled corticosteroid in asthmatic children as evaluated by both symptoms control level and improvement of Pulmonary functions.

\section{METHODS}

The study was carried out at the Pulmonology Unit, Pediatric Department, and Zagazig University Children Hospital in co-operation with the Scientific and Medical Research Center of the Faculty of Medicine, Zagazig University. The study was held over an 18 month period between March 2017 and September 2018.

The research protocol was approved by the Institutional review Board (IRB) of the faculty of medicine Zagazig University. All children's parents gave their informed consent before being included in our study

The Work has been carried out in accordance with the code of Ethics of the World Medical Asssociation (Declaration of Helsinki) for studies involving humans.

\section{Type of the study:}

Our study was designed as a case-control study.

\section{Subjects:}

Subjects included in the study were 2 groups:

The asthmatic group included 75 children aged 5 to 16 years (mean age $8.21 \pm 2.14$ ) diagnosed as bronchial asthma according to The Global Initiative For Asthma (GINA) guidelines, $2016^{[1]}$. They were 37 males and 38 females.

The control group included 66 children, 34 males and 32 females with a mean age of 8.6 \pm 2.41 , who had no evidence of bronchial asthma, allergy or atopy and also had no first degree relatives with bronchial asthma, allergy or atopy.

Patients with chronic lung disease other than bronchial asthma like cystic fibrosis or interstitial lung disease were excluded from the study.

\section{Methodology:}

All children included in the study were subjected to complete history taking and evaluating the effect of BCLI single careful clinical examination. A blood sample for genotyping was collected

Children with bronchial asthma had their level of asthma symptom control assessed and Treatment was prescribed according to the step up approach as determined by GINA guidelines [1]. Serum total IgE and eosinophilic count were obtained.

Regular follow up at the outpatient clinic was done at least monthly where adherence to medications was emphasized, control level was assessed and adjustment of the treatment was done accordingly.

Three months after treatment we assessed the level of symptoms control and the composite asthma severity index score was calculated as described by Wildfire Et al [7]. The online forum is available at WWW.asthmaseverity.org.

Pulmonary function test was done for all asthmatic children initially and repeated 3 months after treatment using the Jaeger Master Screen ${ }^{\mathrm{TM}}$ IOS, version 5.2 manufactured by VIASYS Healthcare GmbH, Hochberg, Germany. FEV1, FVC and FEV1/FVC were expressed as percentage of predicted for weight and age according to standardized criteria described by Miller et al [8].

\section{Genotyping:}

Sample: $2 \mathrm{ml}$ of venous blood sample was collected in sterile EDTA containing tubes for DNA extraction

DNA extraction was performed using Gspin $^{\mathrm{TM}}$ Total DNA Extraction Mini Kit (Intron Biotechnology, Korea) according to instruction manual.

For analysis of the NR3C1 BclI Single Nucleotide Polymorphism polymerase chain reaction followed by restriction fragment length polymorphism as described by Pietras et al [9]. was implemented with some modifications.

PCR amplification was done using the following primers, designed by (Intron Biotechnology, Korea); the forward primer was5'-GAGAAATTCACCCCTACCAAC-3', the reverse primer was 5'- 
AGAGCCCTATTCTTCAAACTG-3'.A

reaction volume of $25 \mu \mathrm{l}$ was prepared using $2.5 \mu \mathrm{l} 10 \times$ buffer, $2.5 \mu \mathrm{l} \mathrm{MgCl} 2,2.0 \mu \mathrm{ldNTP}$, $1 \mu \mathrm{l}$ from each of the forward and reverse primers, $0.25 \mu \mathrm{l}$ of the Taq enzyme, $3 \mu \mathrm{l}$ of the extracted DNA and $12.75 \mu \mathrm{l}$ double distilled water.

The following thermal profile was followed: Initial denaturation $95{ }^{\circ} \mathrm{C}$ for 2 minutes, followed by 40 cycles which consists of : 94 ${ }^{\circ} \mathrm{C}$ for 30 seconds, $60{ }^{\circ} \mathrm{C}$ for 30 seconds, $72{ }^{\circ} \mathrm{C}$ for 30 seconds, and a final step at $72^{\circ} \mathrm{c}$ for 7 minutes to finish the reaction.

Restriction digestion reaction was done by mixing10 $\mu \mathrm{l}$ of PCR products with $1.2 \mu \mathrm{l}$ of bcl-I restriction endonucleases, $2 \mu \mathrm{l}$ of $10 \times$ loading buffer and $7 \mu \mathrm{L}$ of distilled water and incubation at $37^{\circ} \mathrm{C}$ for 10 hours.

The digested product samples were prepared and electrophoresed on agarose. The electric current was set at $100 \mathrm{~mA} \& 70$ volts for about one hour, and then the gel was visualized under UV transilluminator with 100 base pair ladder and photographed.

Interpretation: The presence of one restriction site hallmarks the wild-type allele while its absence indicates the mutated allele, homozygous typical - wild- allele CC genotype resulted in two digestion fragments of 267 and $151 \mathrm{bp}$ length, the homozygous mutant allele GG genotype resulted in one fragment of $418 \mathrm{bp}$ length, while the presence of heterozygote $\mathrm{CG}$ genotype resulted in 3 base pair lengths of 418- 267 and 151 bp length. (Figure 1)

\section{Statistical analysis:}

Statistical Package for the Social Sciences ((SPSS version 20.0) IBM Corp., Armonk, NY, USA) was used to analyze the Data.

$\mathrm{P}$ value of $<0.05$ was considered statistically significant and value $<0.001$ was considered highly significant. Independent $\mathrm{t}$ test, $\mathrm{Chi}$ square test $\left(\mathrm{X}^{2}\right)$, ANOVA test and Kruskal Wallis test were used when appropriate.

\section{RESULTS}

The mean age for the asthma group was $8.21 \pm 2.14$ and that of the control group was $8.6 \pm 2.41$ with no statistically significant difference. Also, there was no statistically significant difference as regard sex or body mass index the demographic data of the studied group is summarized in (table 1).

The Bcl I single nucleotide polymorphism of the Glucocorticoid receptors (GR) NR3C1 gene $\mathrm{CC}, \mathrm{CG}$ and $\mathrm{GG}$ among asthma group were $45.5 \%, 33.3 \%$ and $21.3 \%$ respectively. While, among control group the frequencies were $46.9 \%, 36.3 \%$ and $16.6 \%$ respectively. No statistically significant difference was found between asthmatic group and the control group as regard genotype. Also the $\mathrm{G}$ allele and the $\mathrm{C}$ allele frequency distribution were not different between children with bronchial asthma and the children of the control group. The data are summarized in (table 2).

We also found no significant association between different genotypes and different asthma characteristics including age of onset of asthma, family history of asthma, exercise induced asthma, atopic status including total IgE level and Eosinophilic count these data are summarized in (table 3 ).

At the beginning of the study, 23 children (30.7\%) had controlled asthma symptoms, 28 children $(37.3 \%)$ had partially controlled and $24(32.0 \%)$ had uncontrolled symptoms. There was no statistically significant difference between different genotypes as regards asthma control or pulmonary function tests at the beginning of the study. The data are summarized in (table 4)

After 3 months of treatment with ICS 35 children $(46.7 \%)$ had controlled asthma symptoms, while 32 children $42.7 \%$ had partially controlled and 8 children $10.7 \%$ had uncontrolled symptoms.

Among Children with the CC genotype 58.8 $\%$ had controlled asthma symptoms 3 months after treatment as compared to $48 \%$ and 18.8 of children with the CG and the GG genotypes respectively. Meanwhile, among children with the GG genotype $25 \%$ of children with the GG genotype had uncontrolled asthma symptoms as compared to $4 \%$ and $8.8 \%$ of children with the CG and the $\mathrm{CC}$ genotypes respectively. The difference was statistically significant $P$ value of 0.04 . There was also statistically significant difference among the 3 genotypes as regards 
the FEV1\% measured 3 months after treatment. Data are summarized in (table 5) The mean Composite asthma severity index score was significantly higher in children with the GG genotype as compared to children with the $\mathrm{CG}$ and $\mathrm{CC}$ genotypes. (Figure 2)

Table1. Demographic characteristics of the studied groups

\begin{tabular}{|c|c|c|c|c|c|}
\hline & & $\begin{array}{c}\text { Asthmatic } \\
\text { group }(\mathrm{N}=75)\end{array}$ & $\begin{array}{l}\text { Control group } \\
(\mathrm{N}=66)\end{array}$ & $t / X^{2}$ & $\mathbf{P}$ \\
\hline \multicolumn{2}{|c|}{ Age $($ mean \pm SD $)$} & $8.21 \pm 2.14$ & $8.6 \pm 2.41$ & -0.89 & 0.37 \\
\hline \multirow{2}{*}{ Sex } & Male N (\%) & $37(49.3 \%)$ & $34(51.5 \%)$ & \multirow{2}{*}{0.067} & \multirow[t]{2}{*}{0.79} \\
\hline & Female N (\%) & $38(50.7 \%)$ & $32(48.5 \%)$ & & \\
\hline \multicolumn{2}{|c|}{ BMI (mean+SD) } & $22.55 \pm 3.32$ & $22.71 \pm 3.65$ & 0.974 & 0.331 \\
\hline \multicolumn{2}{|r|}{ Total } & 75 & 66 & & \\
\hline
\end{tabular}

Table2.Genotype and allele distribution among studied groups

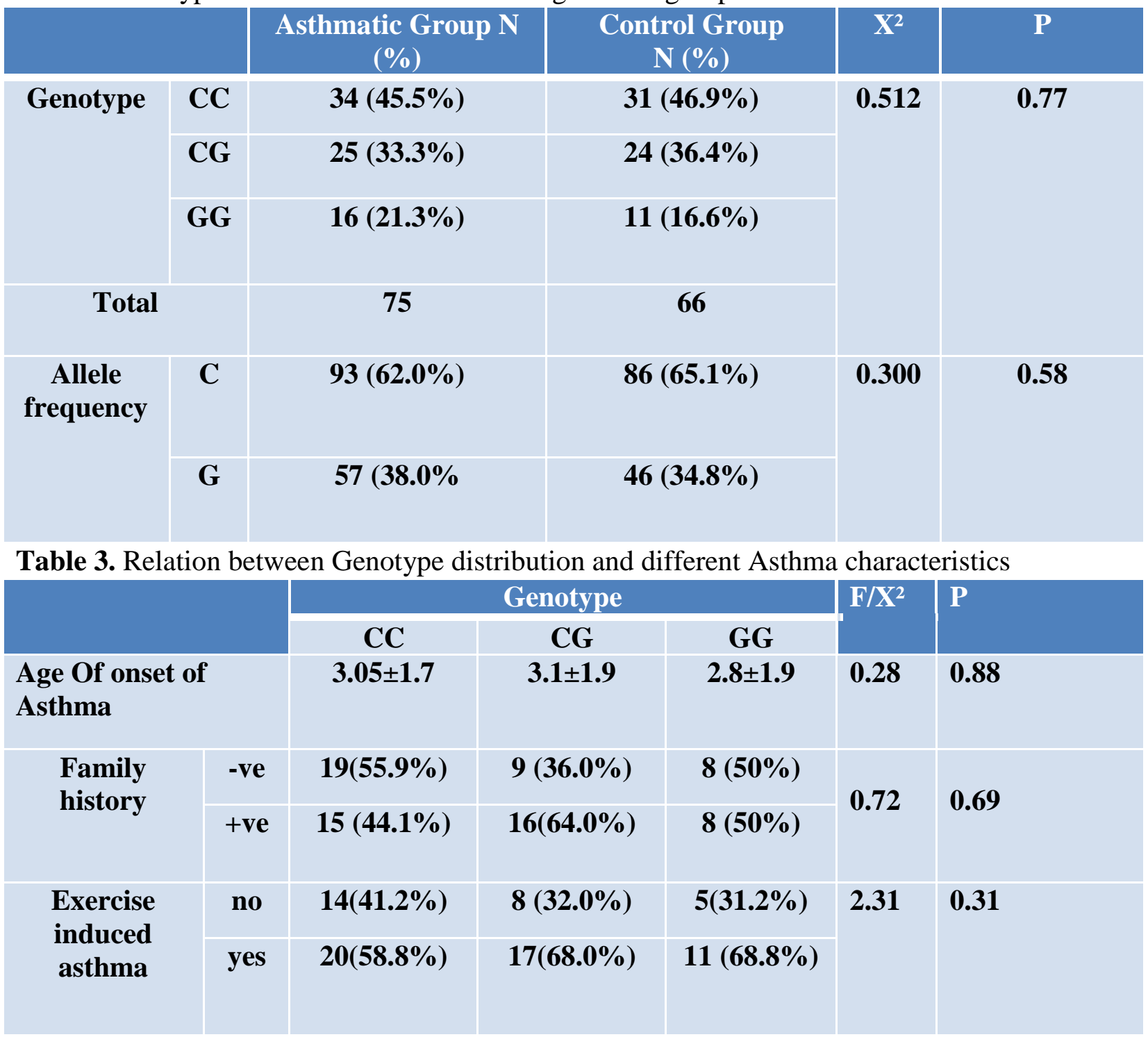




\begin{tabular}{|c|c|c|c|c|c|}
\hline $\begin{array}{c}\text { Total IgE } \\
\text { level(IU/ml) } \\
\text { (Median, IQR) }\end{array}$ & $\begin{array}{c}113.9 \\
(57-267)\end{array}$ & $\begin{array}{c}124 \\
(63.2-312)\end{array}$ & $\begin{array}{c}248 \\
(117-352)\end{array}$ & 3.42 & 1.98 \\
\hline $\begin{array}{l}\text { Eosinophilic } \\
\text { count/UL } \\
\text { (Median,IQR) }\end{array}$ & $\begin{array}{c}400 \\
(260-700)\end{array}$ & $\begin{array}{c}500 \\
(200-700)\end{array}$ & $\begin{array}{c}500 \\
(300-600)\end{array}$ & 0.42 & 0.81 \\
\hline
\end{tabular}


Table 4. Level of asthma symptom Control and pulmonary function test at the beginning of the study:

\begin{tabular}{|c|c|c|c|c|c|}
\hline & \multicolumn{3}{|c|}{ Genotype } & \multirow[t]{2}{*}{$\mathbf{X}^{2}$} & \multirow[t]{2}{*}{$\mathbf{P}$} \\
\hline & $\mathrm{CC}$ & CG & GG & & \\
\hline $\begin{array}{l}\text { Level of asthma } \\
\text { control: }\end{array}$ & $\mathbf{N}(\%)$ & $\mathbf{N}(\%)$ & $\mathbf{N}(\%)$ & \multirow{4}{*}{0.36} & \multirow{4}{*}{0.54} \\
\hline $\begin{array}{l}\text { Children with } \\
\text { controlled asthma }\end{array}$ & $10(29.4 \%)$ & $9(36.0 \%)$ & $4(25.0 \%)$ & & \\
\hline $\begin{array}{l}\text { With partially } \\
\text { controlled asthma }\end{array}$ & $14(41.1 \%)$ & $10(40.0 \%)$ & $4(25.0 \%)$ & & \\
\hline $\begin{array}{l}\text { With uncontrolled } \\
\text { asthma }\end{array}$ & $10(29.4 \%)$ & $6(24.0 \%)$ & $8(50.0 \%)$ & & \\
\hline \multicolumn{6}{|l|}{$\begin{array}{c}\text { Pulmonary function } \\
\text { tests: }\end{array}$} \\
\hline $\begin{array}{c}\text { FEV1\% } \\
(\text { mean } \pm \text { SD })\end{array}$ & $77.25 \pm 9.14$ & $77.23 \pm 10.3$ & $73.23 \pm 10.0$ & 1.06 & 0.35 \\
\hline $\begin{array}{c}\text { FEV1/FVC\% } \\
(\text { mean } \pm \text { SD })\end{array}$ & $76.53 \pm 7.06$ & $76.36 \pm 8.25$ & $73.05 \pm 10.6$ & 1.02 & 0.39 \\
\hline
\end{tabular}

Table 5. Level of asthma symptom Control and pulmonary function test 3 months after treatment:

\begin{tabular}{|c|c|c|c|c|c|}
\hline & \multicolumn{3}{|c|}{ Genotype } & \multirow[t]{2}{*}{$\mathbf{X}^{2}$} & \multirow[t]{2}{*}{$\mathbf{P}$} \\
\hline & $\mathrm{CC}$ & CG & GG & & \\
\hline $\begin{array}{l}\text { Level of asthma } \\
\text { control: }\end{array}$ & $\mathbf{N}(\%)$ & $\mathbf{N}(\%)$ & $\mathbf{N}(\%)$ & & \\
\hline $\begin{array}{l}\text { Children with } \\
\text { controlled asthma }\end{array}$ & $20(58.8 \%)$ & $12(48.0 \%)$ & $3(18.8 \%)$ & \multirow[t]{3}{*}{9.65} & \multirow[t]{3}{*}{$0.046^{*}$} \\
\hline $\begin{array}{l}\text { With partially } \\
\text { controlled asthma }\end{array}$ & $11(32.4 \%)$ & $12(48.0 \%)$ & $9(56.3 \%)$ & & \\
\hline $\begin{array}{l}\text { With uncontrolled } \\
\text { asthma }\end{array}$ & $3(8.8 \%)$ & $1(4.0 \%)$ & $4(25.0 \%)$ & & \\
\hline \multicolumn{6}{|l|}{$\begin{array}{l}\text { Pulmonary function } \\
\text { tests: }\end{array}$} \\
\hline $\begin{array}{c}\text { FEV1\% } \\
(\text { mean+SD) }\end{array}$ & $84.7 \pm 6.41$ & $82.01 \pm 8.46$ & $78.65 \pm 8.84$ & 3.46 & $0.037 *$ \\
\hline $\begin{array}{c}\text { FEV1/FVC\% } \\
(\text { mean } \pm \text { SD })\end{array}$ & $80.82 \pm 5.6$ & $78.82 \pm 6.2$ & $76.5 \pm 6.7$ & 5.01 & 0.08 \\
\hline
\end{tabular}




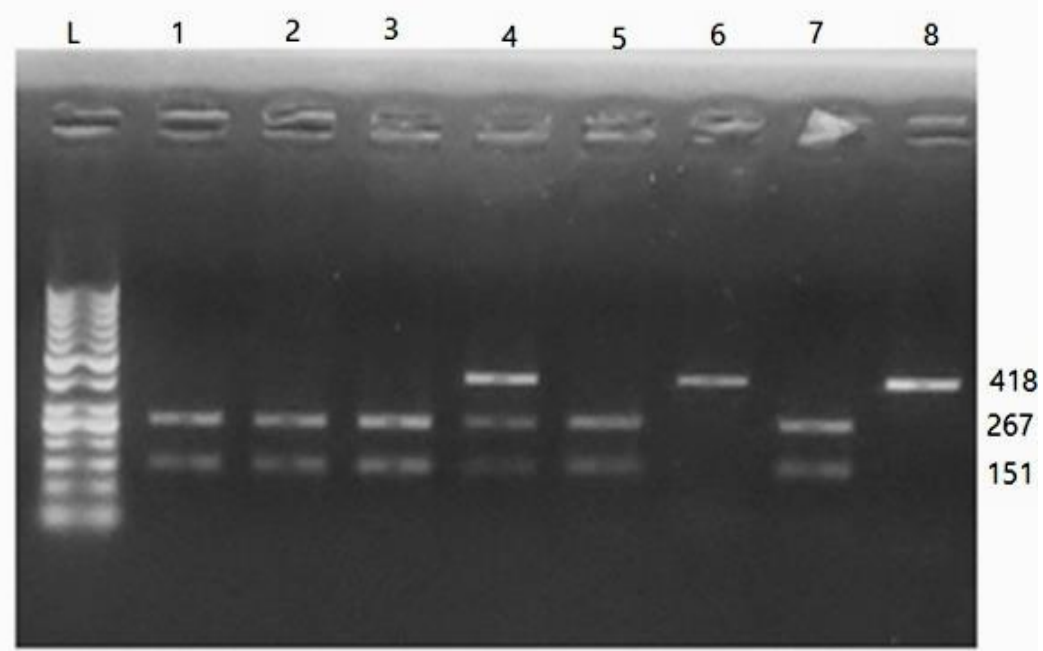

Figure 1. Photographing Gel Electrophoresis results of PCR amplification and restriction Products .

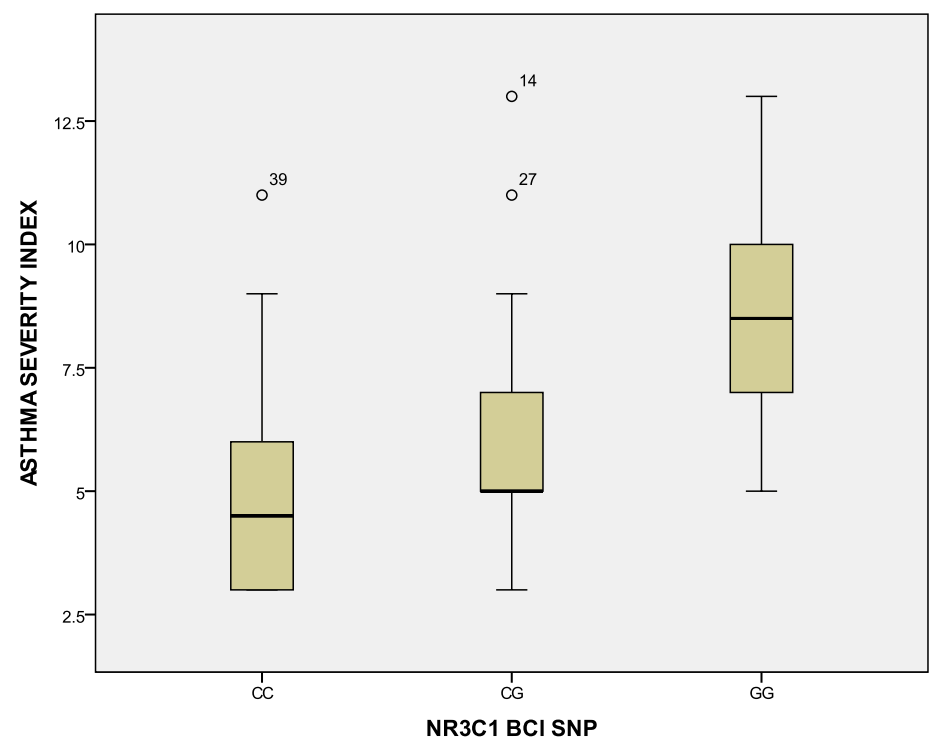

Figure 2. comparison of the asthma severity index score among different genotypes

\section{DISCUSSION}

Precision or personalized medicine is based on adjusting the treatment approach of diseases based on the personal genetic profile, disease mechanism, and the patient's life style [10]. An important aspect of precision medicine is the pharmacogenetics. Pharmacogenetics is a new field of research which links genetic variation with drug effects to determine impact on pharmacology and clinical application [11].

Our study aimed at studying the pharmacogenetics of the Inhaled corticosteroids in treatment of asthma on children by studying the Glucocorticoid receptor NR3C1 single nucleotide polymorphism which was linked in previous studies to the sensitivity to glucocorticoids.
Our study was a case control study which included 75 asthmatic children who were indicated for Inhaled corticosteroids therapy as a controller and 66 healthy control children. Both asthma group and control groups were closely matched regarding their age and gender distribution with no significant gender between both groups.

We investigated the NR3C1 BCII SNP by using PCR-RFLP technique. In contrary to our research hypothesis, our results showed no significant association between different genotypes and bronchial asthma in the studied population. Moreover, we did not find any correlation between allele frequency and the occurrence of bronchial asthma among our children. 
Several researchers have studied the effects of Glucocoticoid receptors NR3C1 gene polymorphism on the development of bronchial asthma. Similar to our results, a large study by Vink et al, including 2 independent cohorts, found no significant association with bronchial asthma susceptibility in adolescents [12]. Similar results were also reported by Szczepankiewicz et al, [13]. and Cheng et al, [14]. Panek and colleagues [6]. also reported no statistically significant differences in the frequencies of the GRNR3C1 gene polymorphism between asthma patients and healthy controls, although the same group had previously reported increased risk of asthma among the GG homozygote genotype in their preliminary study [9]. Moreover, a study that evaluated the allele frequency among children with high versus low asthma predictive index also found no significant difference [15].

Contradictory to our results, significant association of the GG homozygous genotype with bronchial asthma was found in 2 studies by Kmyta et al, [16]. and Yun et al, [17]. On the other hand, a preliminary Egyptian study found higher frequency of the $\mathrm{C}$ allele among adults with asthma [18]. A similar result was also reported by Murzina et al, [19].

Asthma is a multi-factorial disease and the fact that different genetic associations are not replicated in different studies, reflects the complex interactions between different genetic and environmental factors that underlie such a complex disease. As with other diseases with Multi-factorial inheritance, individual genes do not account for a large amount of the heritability of asthma [20]. Possibly our relatively small sample size could not identify statistically significant association.

We investigated the distribution of the NR3C1 gene polymorphism in atopic and non atopic asthmatic children. We found no association between different genotypes and either the serum total IgE, or the eosinophilic count. Similar to our results Mohammed et al, ${ }^{[18]}$ reported no association with the atopic status in asthmatics.

Our results showed that patients with the $\mathrm{CC}$ and CG genotypes were significantly associated with good asthma symptom control after 3 months of treatment as compared to patients with the GG genotype. 58\% of patients with $\mathrm{CC}$ and $48 \%$ of patients with CG genotypes achieved good control while only $18 \%$ of patients with the GG genotype did. Similarly patients with the GG genotype had lower FEV1\% when evaluated 3 months after treatment as compared to the $\mathrm{CC}$ and $\mathrm{CG}$ genotypes.

In agreement with our results, Kmyta et al, [20]. showed that patients with the GG polymorphism had poor asthma control. The association between the GG genotype and poor lung function was even reported in patients with cystic fibrosis in an earlier study [21]. Also In agreement with our results, Mohamed et al, [18]. reported higher frequency of the $\mathrm{C}$ allele among glucocorticoid sensitive asthmatic patients as determined by improving FEV1\% of more than $30 \%$ after a course of oral corticosteroids. And similar results were reported by Yun et al, [17].

Contradicting our study is the study by Keskin et al, [22]. who reported better response to inhaled corticosteroids among children with the GG genotype. Unlike our study their primary outcome was the improvement in the FEV1\% 4 hours after ICS during asthma exacerbation. This could be explained by different mechanisms of action underlying the rapid effect of ICS being nongenomic effect as opposed to the delayed genomic mechanism behind the antiinflammatory effect [23]. Interestingly, researchers have found that while Skin sensitivity to budesonide was enhanced in patients with the GG genotype, white blood cells of the GG subjects were less sensitive to dexamethasone in vitro [21].

In our study we evaluated the association between Glucocorticoid receptors NR3C1 gene polymorphism and the composite asthma severity index score (CASI). Our results showed that the CASI score was statistically higher in children with the GG genotype. The CASI is a subjective measure that evaluates several aspects of asthma severity on multiple aspects, which include symptom control, medication use, lung function tests and 
exacerbations. This score was advised by GINA guidelines [1]. as a tool to assess asthma severity in children and adolescents. The CASI enables to determine the difference in severity between patients who may appear similar only on the basis of symptom control, thus we believe that it is a useful tool for clinical research especially in the area of pharmacogenetics [24].

Our study has some limitations including the small number of children included in the study and also being a cross sectional rather than a prospective randomized study.

We recommend that larger multicenter studies evaluating the pharmacogenetic markers for inhaled corticosteroids, preferably designed as genotyped stratified prospective trials, are needed to assess the application of such studies in clinical practice.

In conclusion: our study showed no significant difference in the frequency of $B c l I$ polymorphisms of the NR3Cl gene distribution between asthmatic and non asthmatic children. Among asthmatic children, however, the presence of the GG genotype was associated with decreased response to inhaled corticosteroids and worse composite asthma severity index score.

Acknowledgement: We would like to express our gratitude to the Scientific and Medical Research Center of the Faculty of Medicine, Zagazig University for their support.

\section{Declaration of interest}

The authors report no conflicts of interest. The authors alone are responsible for the content and writing of the paper.

Funding information: None declared REFERENCES

1- GINA, Global Initiative for Asthma. Global Strategy for Asthma Management and Prevention. 2016 [Available from] www.ginasthma.org.

2- Marks G, Pearce N, Strachan D, Asher I, Ellwood P. Global Burden of Disease due to Asthma. In: The Global Asthma Report 2018. Auckland, New Zealand: Global Asthma Network, 2018. available from: https://www.globalasthmareport.org

3- Farzan N, Vijverberg SJ, Arets HG, Raaijmakers JA, Maitland-van der Zee AH. Pharmacogenomics of inhaled corticosteroids and leukotriene modifiers: a systematic review. Clin Exp Allergy. 2017; 47(2):271-293.

4- Duong-Thi-Ly H, Nguyen-Thi-Thu H, Nguyen-Hoang L, Nguyen-Thi-Bich $H$, Craig TJ, Duong-Quy S. Effects of genetic factors to inhaled corticosteroid response in children with asthma: a literature review. J Int Med Res. 2017; 45(6):18181830.

5- Keskin O, Uluca Ü, Birben E, Coşkun Y, Ozkars MY, Keskin M, et al. Genetic associations of the response to inhaled corticosteroids in children during an asthma exacerbation. Pediatric Allergy and Immunology. 2016; 27(5):507-13.

6- Panek M, Pietras T, Fabijan A, Milanowski M, Wieteska L, Gorski P, et al. Effect of glucocorticoid receptor gene polymorphisms on asthma phenotypes. Experimental and therapeutic medicine. 2013; 5(2):572-80.

7- Wildfire JJ, Gergen PJ, Sorkness CA, Mitchell HE, Calatroni A, Kattan M, et al. Development and validation of the Composite Asthma Severity Index-an outcome measure for use in children and adolescents. Journal of Allergy and Clinical Immunology. 2012;129(3):694701.

8- Miller MR, Hankinson $J$, Brusasco V, Burgos F, Casaburi R, Coates A, et al. Standardisation of spirometry. European respiratory journal. 2005;26(2):319-38.

9- Pietras T, Panek M, Tworek D, Oszajca K, Wujcik R, Gorski P, et al. The Bcl I single nucleotide polymorphism of the human glucocorticoid receptor gene hGR/NR3C1 promoter in patients with bronchial asthma: pilot study. Molecular biology reports. 2011;38(6):3953-8.

10-Farzan N, Vijverberg SJ, Kabesch M, Sterk PJ, Maitland-van der Zee AH. The use of pharmacogenomics, epigenomics, and transcriptomics to improve childhood asthma management: Where do we stand? Pediatric pulmonology. 2018;53(6):83645.

11- Hicks, J. K., \& McLeod, H. L. (2017). Chapter 6 - Pharmacogenetics and Pharmacogenomics. In S. P. David (Ed.), 
Genomic and Precision Medicine (Third Edition) (pp. 89-107). Boston: Academic Press.

12- Vink NM, Postma DS, Nieuwenhuis MA, Koppelman GH, Rosmalen JG, Boezen HM. No associations of the mineralocorticoid and glucocorticoid receptor genes with asthma. European Respiratory Journal. 2012; 40(6):1572-4.

13-Szczepankiewicz A, Breborowicz A, Sobkowiak P, Popiel A. No association of glucocorticoid receptor polymorphisms with asthma and response to glucocorticoids. Advances in medical sciences. 2008; 53(2):245.

14- Cheng Z, Dai LL, Liu Q, Liu M, Wang Q, $\mathrm{Li} \mathrm{PF}$, et al. Correlation between polymorphisms in the glucocorticoid receptor gene $\mathrm{NR} 3 \mathrm{C} 1$ and susceptibility to asthma in a Chinese population from the Henan Province. Genetics and molecular research : GMR. 2016;15(2).

15- Morales M, Flores C, Pino K, Angulo J, Lopez-Lastra M, Castro-Rodriguez JA. Urinary leukotriene and $\mathrm{Bcl}$ I polymorphism of glucocorticoid receptor gene in preschoolers with recurrent wheezing and high risk of asthma. Allergologia et immunopathologia. 2016;44(1):59-65.

16- Kmyta VV, Garbuzova VY, Prystupa EN, Prystupa LN. Bcll polymorphism of glucocorticoid receptor gene in patients with bronchial asthma with obesity. Cytology and Genetics. 2016 May 1;50(3):178-82.

17- Yun Z, Wang D, Qu Y. Relationship between bronchial asthma and glucocorticoid receptor gene bcl-I single nucleotide polymorphism. Discussion of Clinical Cases. 2018;5(3):8.
18- Mohamed NA, Abdel-Rehim AS, Farres $\mathrm{MN}$, Muhammed HS. Influence of glucocorticoid receptor gene NR3C1 646 $\mathrm{C}>\mathrm{G}$ polymorphism on glucocorticoid resistance in asthmatics: a preliminary study. Central-European journal of immunology. 2015;40(3):325-30.

19- Hizawa N. Genetics of Asthma. Journal of General and Family Medicine 2015;6(4):252-259.

20- Kmyta V, Prystupa L. Influence of Bcl-1 gene polymorphism of glucocortucoid receptor on phenotypic expressions of bronchial asthma. Clinical and translational allergy. 2015 Dec;5(2):P10

21- Corvol H, Nathan N, Charlier C, Chadelat $\mathrm{K}$, Le Rouzic P, Tabary O, et al. Glucocorticoid receptor gene polymorphisms associated with progression of lung disease in young patients with cystic fibrosis. Respiratory research. 2007;8:88.

22- Keskin O, Farzan N, Birben E, Akel H, Karaaslan C, Maitland-van der Zee AH, et al. Genetic associations of the response to inhaled corticosteroids in asthma: a systematic review. Clinical and translational allergy. 2019;9:2-.

23- Hossny E, Rosario N, Lee BW, Singh M, El-Ghoneimy D, Soh JY, et al. The use of inhaled corticosteroids in pediatric asthma: update. The World Allergy Organization journal. 2016;9:26.

24- Licari A, Brambilla I, Marseglia A, De Filippo M, Paganelli V, Marseglia GL. Difficult versus severe asthma: definition and limits of asthma control in the pediatric population. Frontiers in pediatrics. $2018 ; 6: 170$

To Cite This Article: Khalid MS,Mona MA, Osama AG, Mahmoud TA *.Association between Glucocorticosteroid Receptors (NR3C1) Gene Polymorphism and Bronchial Asthma in Children.ZUMJ 2020;26(1);123-131.DOi: 10.21608/zumj.2019.11975.1204 